\title{
Endothelial progenitor cells relationships with clinical and biochemical factors in a human model of blunted angiotensin II signaling
}

\author{
Lorenzo A Calò ${ }^{1}$, Monica Facco ${ }^{2}$, Paul A Davis ${ }^{3}$, Elisa Pagnin ${ }^{1}$, Lucia Dal Maso ${ }^{1}$, Massimo Puato ${ }^{1}$, \\ Paola Caielli ${ }^{1}$, Carlo Agostini ${ }^{3}$ and Achille C Pessina ${ }^{1}$
}

Angiotensin II (Ang II) is essential for endothelial progenitor cells (EPCs) function as Ang-II-induced oxidative stress causes senescence of EPCs and endothelial dysfunction and Ang II type 1 receptor blockers increase EPCs. Moreover, EPCs activity is dependent on nitric oxide (NO) and heme oxygenase (HO)-1 as these correlate with EPCs senescence and are reduced in hypertensives. Bartter's/Gitelman's syndrome patients (BS/GS), have increased Ang II yet normo/hypotension along with blunted Ang II signaling, reduced oxidative stress, increased NO and HO-1, thus presenting a unique system to explore EPC biology and its relationship with vascular clinical and biochemical correlates. Circulating EPCs, NO-dependent vasodilation (flow-mediated dilation (FMD)) and HO-1 gene expression were characterized in $10 \mathrm{BS} / \mathrm{GS}$ patients and in 10 normotensive subjects. EPCs defined by cell surface antigens CD34+kinase-insert domain receptor (KDR+), CD133+KDR+ and CD133+CD34+KDR+ cells were quantitiated via direct three-color flow-cytometry analysis, HO-1 gene expression by reverse transcription-PCR and FMD by B-mode echo scan of the right brachial artery. Correlation analysis was carried out regarding FMD and EPCs, FMD and HO-1 and EPCs and HO-1. In BS/GS, CD34+KDR+ cell numbers did not differ from controls while CD133+KDR+ and CD133+CD34+ KDR+ cell numbers were higher. HO-1 gene expression, as well as FMD, was higher in BS/GS compared with controls. Both CD133+KDR+ and CD133+CD34+KDR+ strongly correlated with both FMD and HO-1. FMD and HO-1 were also strongly correlated. These results document in a human system that EPC numbers and specific populations are related to important clinical and biochemical factors involved in cardiovascular (CV) status and reaffirm the utility of BS/GS patients as a useful system to investigate EPC's role(s) in the pathophysiology of cardiovascular remodeling in humans.

Hypertension Research (2011) 34, 1017-1022; doi:10.1038/hr.2011.72; published online 9 June 2011

Keywords: cardiovascular remodeling; EPC; heme oxygenase-1; nitric oxide

\section{INTRODUCTION}

Alteration of the vascular endothelium, that is, injury is a primary event in vascular disease. Injury repair, that is, maintenance of normal vasculature, is in part mediated via re-endothelialization achieved by migration and proliferation of endothelial cells from the injury border zone or from adjacent branching blood vessels, as well as via bone marrow-derived endothelial progenitor cells (EPCs). ${ }^{1,2}$ In hypertension, circulating EPCs number is reduced, EPCs function is impaired ${ }^{3}$ and this represents an additional risk factor for cardiovascular (CV) events. In fact, the level of EPCs has been reported to be predictive of CV events, ${ }^{4}$ and the loss of EPCs to have a role in the development of CV disease. Imanishi et al. ${ }^{5}$ have reported that Angiotensin II (Ang II) accelerates the onset of EPCs senescence through enhanced oxidative stress, which in turn leads to the impairment of proliferative activity in EPCs. In addition, the correction of EPCs dysfunction by treatment with Ang II type 1 receptor blockers further points to a role for Ang II and Ang II-mediated oxidative stress in $\mathrm{EPC}^{6,7}$ as well as endothelial dysfunction. These findings suggest that understanding the factors that determine both the number and functionality of EPCs may provide insight into and potential targets for therapies designed to promote normal vascular function via stimulation of EPCs. ${ }^{8}$

Heme oxygenase (HO-1) is a potent antioxidant protein ${ }^{9}$ that acts on heme, producing $\mathrm{CO}$ and biliverdin, which is further metabolized to bilirubin, a potent antioxidant itself. ${ }^{10} \mathrm{HO}-1$ has been shown to be induced by Ang $\mathrm{II}^{11}$ and HO-1 has been reported to reduce Ang IIinduced oxidative stress. ${ }^{12}$ Upregulation of HO-1 protects against vascular diseases, including atherosclerosis via promoting re-endothelialization, inducing anti-inflammatory activities, inhibiting smooth-muscle-cell proliferation, regulating vascular tone and by increasing cellular antioxidant activities. ${ }^{13}$ Recently, Wu et al. ${ }^{14}$ have linked the HO-1 induction effect on re-endothelialization to HO-1's ability to increase the numbers of circulating EPCs and bone marrow

\footnotetext{
${ }^{1}$ Department of Clinical and Experimental Medicine, Clinica Medica 4, School of Medicine, University of Padova, Padova, Italy; ${ }^{2}$ Emathology and Immunology, School of Medicine, University of Padova, Padova, Italy and ${ }^{3}$ Department of Nutrition, University of California, Davis, CA, USA

Correspondence: Dr LA Calò, Department of Clinical and Experimental Medicine, Clinica Medica 4, University of Padova, Via Giustiniani 2, Padova 35128, Italy.

E-mail: renzcalo@unipd.it
}

Received 17 January 2011; revised 22 March 2011; accepted 24 March 2011; published online 9 June 2011 
early and late outgrowth progenitor cells, and to enhance the maturation of bone marrow-derived progenitor cells.

Bartter's and Gitelman's syndromes (BS/GS), caused by gene defects in specific kidney transporters and ion channels, are rare human diseases with a prevalence of up to 1 in 40000 . These patients present a puzzling clinical picture characterized by hypokalemia, sodium depletion, activation of the renin-angiotensin-aldosterone system, with increased plasma levels of Ang II and aldosterone and yet normo/hypotension, reduced peripheral resistance and hyporesponsiveness to pressor agents. ${ }^{15}$ The results of an extensive series of studies from our laboratory have provided mechanistic explanations for these patients' vascular hyporeactivity and absence of CV remodeling. ${ }^{16-20}$ We have documented a blunted Ang II signaling and related pathways $^{21-28}$ in BS/GS patients. In addition, we have reported in BS/GS reduced oxidative stress alongside increased $\mathrm{HO}-1$ gene expression, ${ }^{29,30}$ upregulation of nitric oxide (NO) system ${ }^{31,32}$ and increased NO-dependent vasodilation. ${ }^{19} \mathrm{BS} / \mathrm{GS}$ likely represents a human model of endogenous Ang II type 1 receptor antagonism and produce a mirror image of the alterations found in hypertension. ${ }^{16-20}$ Given these characteristics, the BS/GS model represents a useful system to further investigate the relationship of EPCs dysfunction with the pathogenesis of hypertensive CV end organ damage.

In this study, we have quantitated EPC populations by three-color flow-cytometry analysis of EPC cell surface antigens and used matched clinical data from our cohort of BS/GS patients, flow-mediated dilation (FMD) that evaluates endothelium-dependent response as by assessing dilation of the brachial artery to increased flow, along with peripheral blood mononuclear cell HO-1 gene expression, to assess in a human model the relationship of EPCs with CV pathophysiology.

\section{METHODS}

\section{Patients}

We studied 10 patients from our cohort BS/GS patients (one BS and nine GS), six males and four females, age range $27-58$ years, the same who had previously been assessed for $\mathrm{FMD}^{19}$ and $\mathrm{HO}-1$ gene expression. ${ }^{30}$ All patients have a full biochemical characterization ${ }^{19}$ (Table 1), with nine GS having undergone full genetic analysis and one BS awaiting the results of the genetic screenings
(Table 2). A total of 10 normotensive healthy subjects (six males and four females, age $46.2 \pm 10.5$ years), from the staff of the Department of Clinical and Experimental Medicine, University of Padova were used as control group for EPCs quantitation.

BS/GS patients were taking only potassium supplements, and all subjects were abstained from food, alcohol and caffeine-containing drinks for at least $12 \mathrm{~h}$ before the study.

Informed consent was obtained from all the study participants, and the study protocol was approved by our institutional authorities.

\section{Methods}

Quantification of peripheral blood endothelial progenitor cells. After overnight fast, patients' venous blood samples were obtained from a forearm vein and processed within 1-2 h. Peripheral blood progenitor cells were analyzed for the expression of cell surface antigens with direct three-color analysis using fluorescein isothiocyanate-conjugated, phycoerythrin (PE)-conjugated and allophycocyanin-conjugated monoclonal antibodies (mAbs) by flow-cytometry analysis (FACSCalibur; Becton Dickinson, Franklin Lakes, NJ, USA, http:// www.bd.com), as previously reported. ${ }^{33,34}$ Briefly, before staining with specific $\mathrm{mAbs}$, cells were treated with fetal calf serum for $10 \mathrm{~min}$, and then the samples were washed with buffer containing phosphate-buffered saline and $0.5 \%$ bovine albumin. Thereafter, $150 \mu \mathrm{l}$ of peripheral blood was incubated with $10 \mu \mathrm{l}$ of fluorescein isothiocyanate-conjugated anti-human CD34 mAb (Becton Dickinson), with $5 \mu \mathrm{l}$ of allophycocyanin-conjugated anti-human CD133 mAb (Miltenyi Biotec, Bergisch Gladbach, Germany) and $10 \mu \mathrm{l}$ of PE-conjugated anti-human kinase-insert domain receptor (KDR) mAb (R\&D Systems, Minneapolis, MN, USA), followed by incubation at $4{ }^{\circ} \mathrm{C}$ for $30 \mathrm{~min}$. Unlabeled cells or anti-isotype antibody served as a control. The frequency of peripheral blood cells positive for the above reagents was determined by a two-dimensional sidescatter fluorescence dot-plot analysis of the samples, after appropriate gating. After morphological gating to exclude granulocyte and cell debris, we gated CD34+ peripheral blood cells and then examined the resulting population for dual and triple expression of KDR and CD133. Circulating progenitor cells were defined as $\mathrm{CD} 34+$ or $\mathrm{CD} 133+$ or $\mathrm{CD} 34+\mathrm{CD} 133+$ cells, whereas EPCs were defined as $\mathrm{CD} 34+\mathrm{KDR}+$ or $\mathrm{CD} 133+\mathrm{KDR}+$ and $\mathrm{CD} 34+\mathrm{CD} 133+\mathrm{KDR}+$ cells. For fluorescence-activated cell sorting analysis, 500000 cells were acquired and scored using a FACSCalibur analyzer (Becton Dickinson). Data were processed using the Macintosh CELLQuest software program (Becton Dickinson). The instrument setup was optimized daily by analyzing the expression of peripheral blood lymphocytes labeled with anti-CD4 fluorescein isothiocyanate/CD8 PE/CD3 PECy5/CD45 allophycocyanin four-color combination.

Table 1 Clinical and laboratory data of BS/GS and healthy controls included in the study

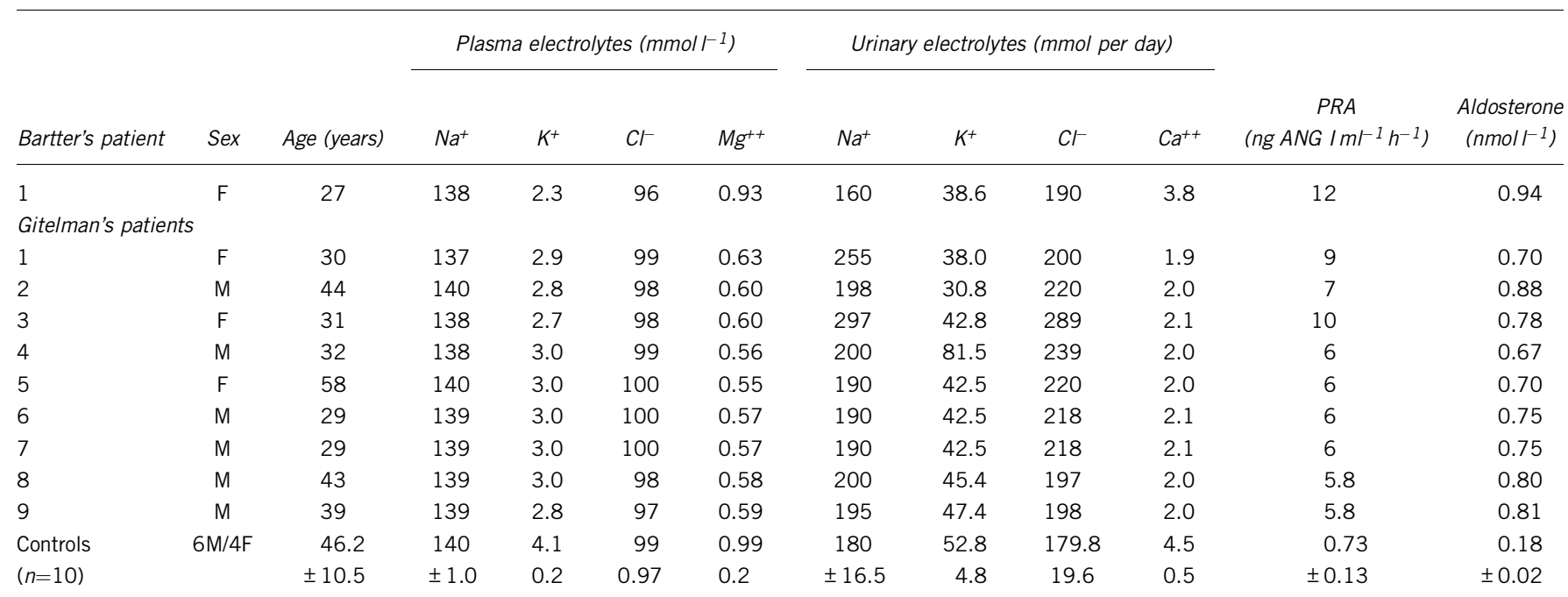

The table reports single data of the patients. Normal values for PRA and plasma aldosterone in our laboratory are $0.2-2.8 \mathrm{ng} \mathrm{ANG} \mathrm{I} \mathrm{ml}^{-1} \mathrm{~h}^{-1}$ and $0.08-0.29 \mathrm{nmol} \mathrm{I}^{-1}$, respectively. Normal values for plasma $\mathrm{Na}^{+}, \mathrm{K}^{+}, \mathrm{Cl}^{-}$and $\mathrm{Mg}^{++}$are $136-145,3.5-5,96-108$ and $0.65-1.05 \mathrm{mmol}^{-1}$, respectively. Normal values for urinary $\mathrm{Na}^{+}, \mathrm{K}^{+}, \mathrm{Cl}^{-}$and $\mathrm{Ca}^{++}$excretion are: $40-220,25-125,110-250$ and $2.5-7.5 \mathrm{mmol}$ per day, respectively. 
Table 2 SLC12A3 mutations identified in the patients with Gitelman's syndrome

\begin{tabular}{|c|c|c|c|c|}
\hline Patient & Exon & Mutation at nucleotide & Homo-heterozygous & Predicted effect on protein \\
\hline 1 & 23 & $2736 \mathrm{G} \rightarrow \mathrm{A}$ & Homozygous & Arg904GIn \\
\hline \multirow[t]{2}{*}{2} & 22 & $2579 \mathrm{C} \rightarrow \mathrm{T}$ & Heterozygous & Arg852Cys \\
\hline & 23 & $2736 \mathrm{G} \rightarrow \mathrm{A}$ & Heterozygous & Arg904GIn \\
\hline \multirow[t]{2}{*}{3} & 15 & $1950 G \rightarrow A$ & Heterozygous & Arg642His or splice donor site truncated SLC12A3 protein \\
\hline & 18 & $2246 \mathrm{G} \rightarrow \mathrm{A}$ & Heterozygous & Gly741Arg \\
\hline \multirow[t]{2}{*}{4} & 22 & $2579 \mathrm{C} \rightarrow \mathrm{T}$ & Heterozygous & Arg852Cys \\
\hline & 23 & $2736 \mathrm{G} \rightarrow \mathrm{A}$ & Homozygous & Arg904Gln \\
\hline \multirow[t]{2}{*}{5} & 22 & $2579 \mathrm{C} \rightarrow \mathrm{T}$ & Heterozygous & Arg852Cys \\
\hline & 23 & $2736 \mathrm{G} \rightarrow \mathrm{A}$ & Heterozygous & Arg904Gln \\
\hline \multirow[t]{2}{*}{6} & 21 & $2542 \mathrm{G} \rightarrow \mathrm{T}$ & Heterozygous & Asp848Tyr \\
\hline & 10 & c.1196_1202dup 7 bp & Heterozygous & Ser402X \\
\hline \multirow[t]{2}{*}{7} & 21 & $2542 \mathrm{G} \rightarrow \mathrm{T}$ & Heterozygous & Asp848Tyr \\
\hline & 10 & c.1196_1202dup 7 bp & Heterozygous & Ser402X \\
\hline \multirow[t]{2}{*}{8} & 17 & c.2089_2095del 7 bp & Heterozygous & pThr697fs \\
\hline & 26 & $2985 G \rightarrow A$ & Heterozygous & Ser402X \\
\hline \multirow[t]{2}{*}{9} & 17 & c.2089_2095del 7 bp & Heterozygous & pThr697fs \\
\hline & 26 & $2985 G \rightarrow A$ & Heterozygous & Ser402X \\
\hline
\end{tabular}

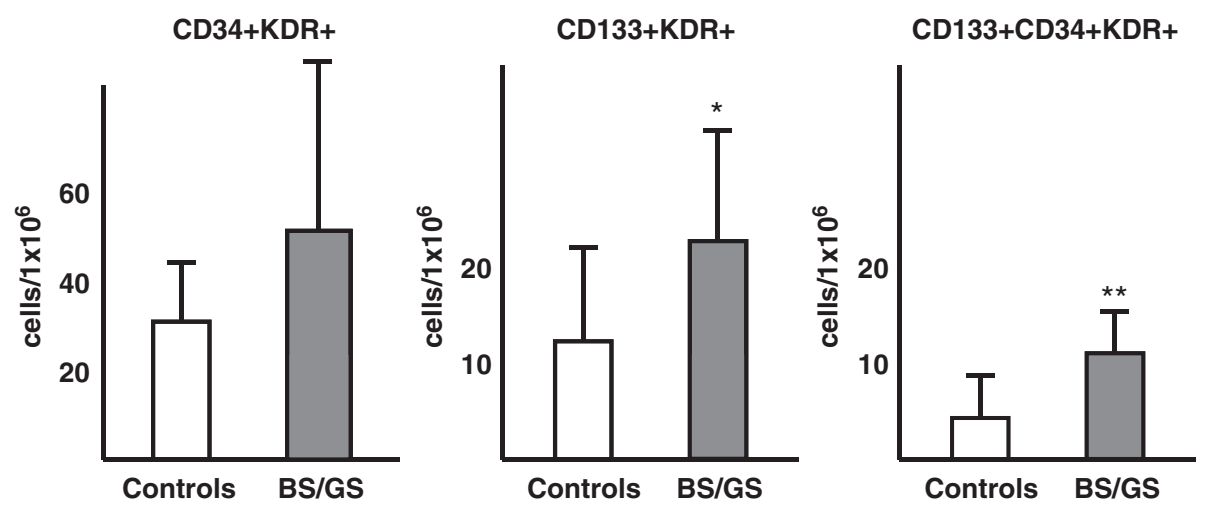

Figure 1 Endothelial progenitor cells (EPCs) number in Bartter's/Gitelman's patients (BS/GS) and healthy subjects (controls). ${ }^{*} P=0.049 ;{ }^{* *} P=0.0003$.

The same trained operator, who was blind to the identity of patients and controls, performed all the tests throughout the study.

Mononuclear cells HO-1 gene expression. HO-1 gene expression was performed using reverse-transcription PCR as previously reported. ${ }^{30}$ Briefly, RNA extracted from peripheral blood mononuclear cells was reverse transcripted using Gene Amp RNA PCR Kit (Applied Biosystems, Foster City, CA, USA), PCR products separated, quantified using a PCR-based densitometric semi-quantitative analysis (NIH image software) and $\beta$-actin PCR products were used as a control gene. The ratio between HO- 1 and $\beta$-actin PCR products (pixel density) was used as an index of $\mathrm{HO}-1$ gene expression. ${ }^{30}$

NO-dependent vasodilation. NO-dependent vasodilation was determined by a B-mode scan of the right brachial artery in longitudinal section above the elbow using a $7-10 \mathrm{MHz}$ linear array transducer and a standard Aspen Advanced Ultrasound System (Acuson, Mountain View, CA, USA) as previously reported. ${ }^{19}$ Briefly, measurements were obtained using an automatic system for computing the brachial artery diameter in real-time by analyzing Bmode ultrasound images. ${ }^{19}$ Endothelium-dependent response was assessed as dilation of the brachial artery to increased flow (FMD). After $1 \mathrm{~min}$ of acquisition for measuring basal diameter, a cuff, placed around the forearm just below the elbow, was inflated for $5 \mathrm{~min}$ at $250 \mathrm{~mm} \mathrm{Hg}$ and then deflated to induce reactive hyperemia. FMD was calculated as the maximal percent increase in the diameter of the brachial artery above baseline. ${ }^{30}$ FMD measure- ments were performed by a single well-trained operator (physician) who was blind on the identity of the patients and controls.

Statistical analysis. Data expressed as mean \pm s.d. were analyzed using the Statview II statistical package (BrainPower, Calabasas CA, USA) and evaluated using Student's ' $t$ ' test for unpaired data and linear regression analysis. Values at a $5 \%$ level or less $(P<0.05)$ were considered significant.

\section{RESULTS}

Figure 1 shows that in BS/GS, two of the three different EPC populations as defined by cell surface antigens assessed were increased relative to their counterparts in controls.

Although both CD133+KDR+ and CD34+CD133+KDR+ cells were higher in BS/GS compared with controls: $22.55 \pm 11.46$ cells/ $1 \times 10^{6}$ vs. $12.00 \pm 9.54, P=0.049$ and $10.33 \pm 3.53$ cells $/ 1 \times 10^{6}$ vs. $3.53 \pm 3.00, P=0.0003$, respectively, $\mathrm{CD} 34+\mathrm{KDR}+$ cells number was not significantly different statistically from controls: $55.00 \pm 37.7$ cells/ $1 \times 10^{6}$ vs. $29.33 \pm 14.28,(P=0.07)$.

As previously reported, ${ }^{30} \mathrm{HO}-1$ gene expression was higher in BS/ GS compared with controls: $0.90 \pm 0.08$ d.u. vs. $0.77 \pm 0.06, P<0.003$ and FMD: $11.0 \pm 2.6 \%$ vs. $8.1 \pm 1.6 \%, P=0.008$ (ref. 19) (Figure 2). 
Figure 3 shows correlation analysis between FMD found for each BS/GS patient and the number of their CD133+ $\mathrm{KDR}+, \mathrm{CD} 34+\mathrm{CD} 133+\mathrm{KDR}+$ cells for each BS/GS patient. Both $\mathrm{CD} 133+\mathrm{KDR}+$ and $\mathrm{CD} 34+\mathrm{CD} 133+\mathrm{KDR}+$ cell numbers were significantly correlated with FMD $(r=0.88 ; P=0.001$ and 0.79 ; $P=0.007$, respectively). The correlation between $\mathrm{CD} 34+\mathrm{KDR}+$ and FMD did not achieve statistical significance $(r=0.51, P=0.13)$.

As shown in Figure 4, both CD133+KDR+ cells and CD34+CD133+ KDR + cells were strongly and significantly correlated with mononuclear cell $\mathrm{HO}-1$ gene expression $(r=0.729 ; P=0.017$ and 0.699; $P=0.024$, respectively), while $\mathrm{CD} 34+\mathrm{KDR}+$ and $\mathrm{HO}-1$ did not correlate $(r=0.28, P=0.42)$.

Figure 5 shows correlation analysis between FMD and HO- 1 that demonstrates that in BS/GS these were strongly and significantly correlated $(r=0.82 ; P=0.004)$.
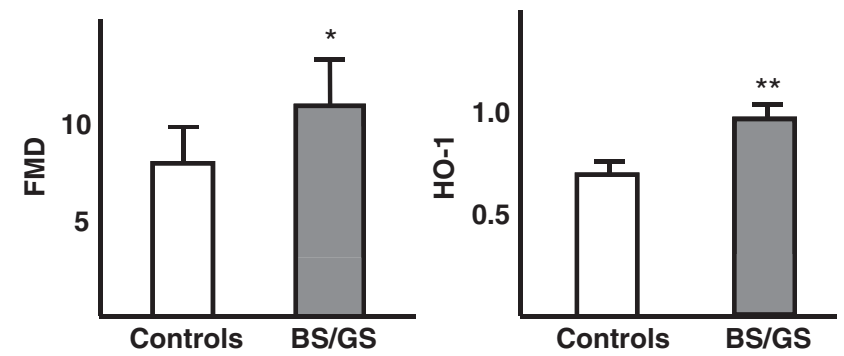

Figure 2 Heme oxygenase $1(H O-1)$ gene expression and flow-mediated dilation (FMD) in Bartter's/Gitelman's (BS/GS) patients and in healthy subjects. ${ }^{*} P=0.008 ;{ }^{* *} P=0.003$.

\section{DISCUSSION}

The current study demonstrated that EPCs number is increased in BS/ GS, a human model of blunted Ang II signaling and vascular hyporeactivity. Moreover, it shows that EPC populations, specifically $\mathrm{CD} 133+\mathrm{KDR}+$ cells and CD34+CD133+KDR+ and FMD were significantly and strongly correlated in BS/GS patients. The correlations noted are likely the result of previously reported relationships between endothelial function and EPC numbers, and function ${ }^{35,36}$ along with the relationship between endothelial number and FMD. ${ }^{37}$ All of these are altered in hypertension, $, 38,39$ and in these alterations oxidative stress has a pivotal role. ${ }^{40,41}$ These results fit with the previously demonstrated absence of oxidative stress, along with increased HO-1

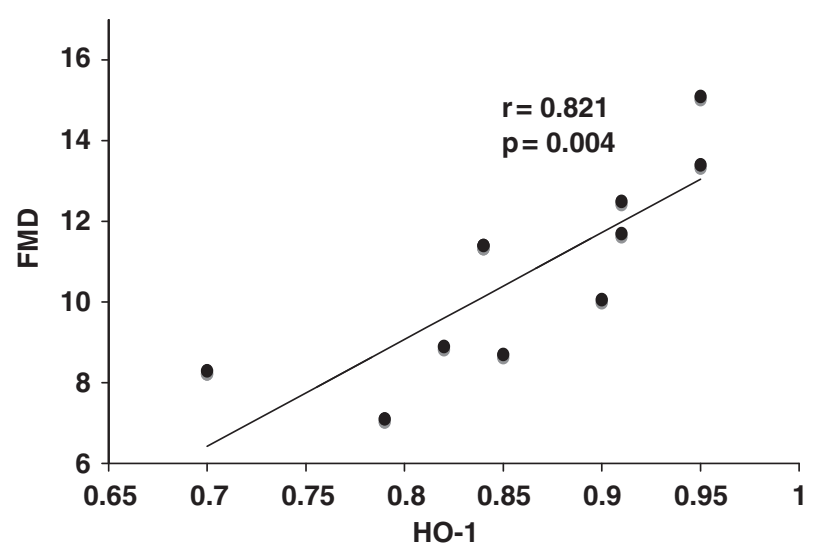

Figure 5 Correlation analysis between nitric oxide (NO)-mediated vasodilation (flow-mediated dilation (FMD)) and heme oxygenase-1 (HO-1) in Bartter's/Gitelman's (BS/GS) patients.
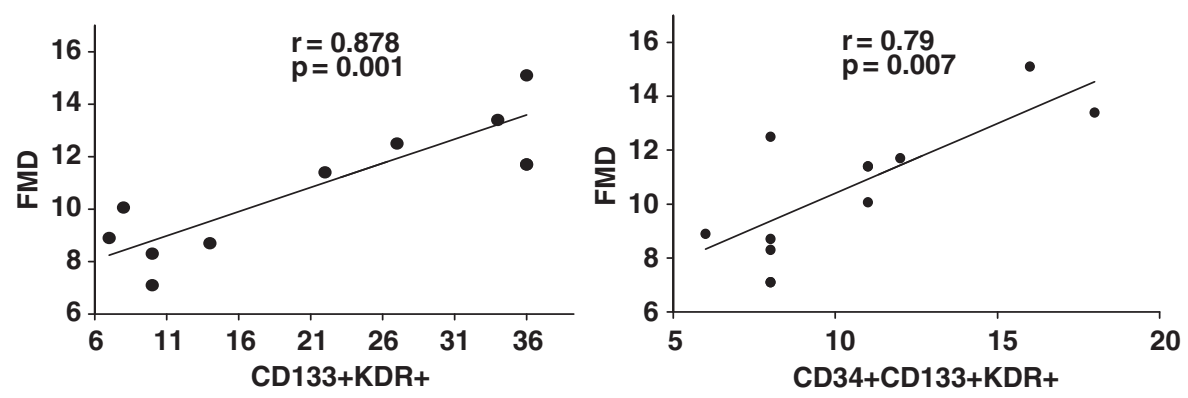

Figure 3 Correlation analysis between nitric oxide (NO)-mediated vasodilation (flow-mediated dilation (FMD)) and CD133+KDR+ cells (left panel) and CD34+CD133+KDR+ cells (right panel) in Bartter's/Gitelman's (BS/GS) patients. FMD is expressed as maximal \% dilation of the brachial artery to increased flow.
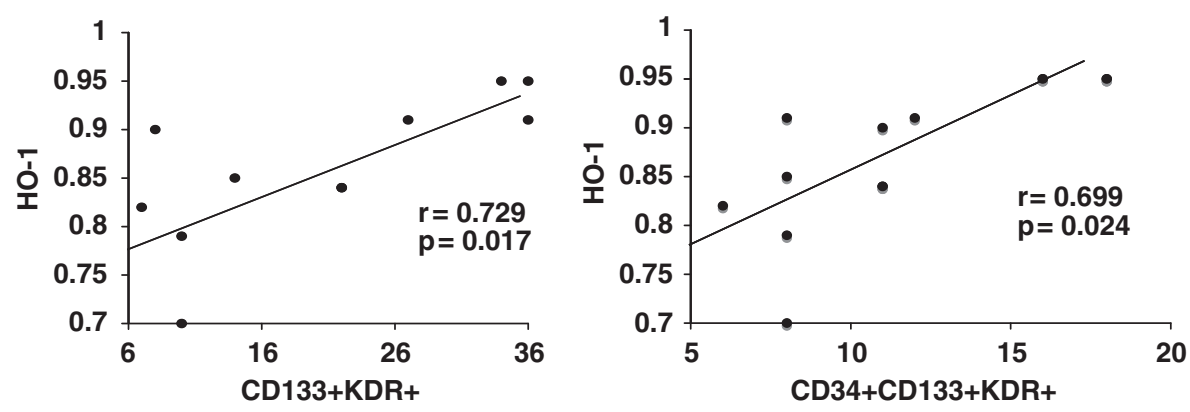

Figure 4 Correlation analysis between heme oxygenase-1 (HO-1) and CD133+KDR+ cells (left panel) and CD34+CD133+KDR+ cells (right panel) in Bartter's/Gitelman's (BS/GS) patients. HO-1 gene expression is expressed as the ratio between HO-1 and $\beta$-actin PCR products (pixel density). 
in BS/GS patients..$^{29,30}$ In addition, despite high levels of Ang II, BS/GS patients have increased FMD and upregulation of NO system, ${ }^{19,31,32}$ both of which are consistent with the increased number of EPC cells found in this study.

The elevated HO- 1 gene expression found in BS/GS patients and the increased levels of EPC observed in this study are consistent with the reports in an animal study that elevating HO-1 increased the numbers of circulating EPCs and bone marrow early and late outgrowth progenitor cells, and enhanced the maturation of bonemarrow-derived progenitor cells. ${ }^{12}$ Moreover, these findings in BS/GS patients are the opposite of those found in hypertensive patients, who have reduced EPCs number, ${ }^{3,38}$ increased oxidative stress ${ }^{42}$ and altered FMD ${ }^{39}$ Furthermore, the increased number of EPC in BS/GS patients further strengthens the role of Ang II type 1 receptor signaling in EPC biology as BS/GS patients have blunted Ang II type 1 receptor signaling. ${ }^{21-28}$ This linkage is further highlighted by the recent report of the beneficial effects of Ang II type 1 receptor blockers on EPCs number and function in hypertensive patients. ${ }^{6,7}$ The extent to which the reported benefits may be derived from blocking Ang II type 1 receptors or signaling via Ang II type 2 receptors remains to be defined, although our recently published study, showing that in BS/GS, Ang II signaling via type 2 receptors is activated, ${ }^{28}$ suggests that Ang II type 2 receptor signaling activation is potentially involved in the beneficial effects on EPCs. Finally, the increased numbers of EPCs in BS/GS support the findings of Rosso et al. ${ }^{43}$ have shown inverse relationships between oxidative stress, senescence and EPC numbers as oxidative stress in BS/GS is reduced.

The relationship of HO-1 levels and EPC has been the subject of several recent reports. As noted earlier, Wu et al. ${ }^{14}$ have shown that increasing HO-1 levels increases EPCs. The current study showed strong and significant correlations between $\mathrm{HO}-1$ gene expression and $\mathrm{CD} 133+\mathrm{KDR}+$ and $\mathrm{CD} 34+\mathrm{CD} 133+\mathrm{KDR}+$ numbers in BS/GS patients, further confirming and extending the linkage between HO1 and EPCs to a human patient population. The link between HO-1 levels and EPCs appears to be mediated in part via HO-1 effects on calcitonin gene-related peptide. Zhou et al. ${ }^{44}$ showed, in fact, that induction of the vasorelaxant calcitonin gene-related peptide, which is reduced in hypertensive patients, prevents circulating EPCs senescence and reversed Ang-II-induced senescence of EPCs. Calcitonin generelated peptide synthesis has been reported to be stimulated by HO-1/ $\mathrm{CO}$ pathway as well as related to stimulation of NO production. ${ }^{45}$

Of note, HO-1 and CD34+KDR+ cell numbers, as well as FMD and $\mathrm{CD} 34+\mathrm{KDR}+$, showed no significant correlation in our study. We do not have an explanation for the unchanged CD34+KDR+ in BS/GS and their lack of correlation of with HO-1 and FMD. The EPCs phenotypes population, that is, those expressing at least one immaturity/stemness marker such as CD34 or CD133 and at least one endothelial antigen (usually KDR), likely have different biological meaning, as the exact surface phenotype of EPCs is not known and no single antigenic combination can unequivocally identify EPCs. ${ }^{8,46,47}$ Therefore, clinical correlation data such as provided by our study are useful to attribute more biological relevance to one putative EPC phenotype vs. the others. For example, one could speculate that $\mathrm{CD} 34+\mathrm{KDR}+$ cell phenotype may correlate with pathological vascular damage and increased $\mathrm{CV}$ risk, ${ }^{48}$ while $\mathrm{CD} 133+\mathrm{KDR}+$ and $\mathrm{CD} 34+\mathrm{CD} 133+\mathrm{KDR}+$ are likely related to oxidative status and endothelial function as suggested by their status in BS/GS that is, increased $\mathrm{CD} 133+\mathrm{KDR}+$ and $\mathrm{CD} 34+\mathrm{CD} 133+\mathrm{KDR}+$ and unchanged $\mathrm{CD} 34+\mathrm{KDR}+$, which fits with the biochemical, molecular and functional picture of good endothelial status reported in these patients. ${ }^{16-23,26-28}$
In conclusion, the study documents in a human system that EPC numbers and specific populations are related to important clinical and biochemical factors involved in $\mathrm{CV}$ status. These results alongside the ongoing studies in our laboratory to quantitate calcitonin gene-related peptide and EPC status for example, senescence and proliferation in BS/GS, reaffirm the utility of BS/GS patients as a useful system to investigate EPC's role(s) in the pathophysiology of CV remodeling in humans.

\section{CONFLICT OF INTEREST}

The authors declare no conflict of interest.

\section{ACKNOWLEDGEMENTS}

We are grateful to the non-profit Foundation for Advanced Research in Hypertension and Cardiovascular Diseases (FORICA), Padova, Italy, for its support. This study has been supported in part by a grant from Associazione Rene-Onlus 'Arturo Borsatti', Padova, Italy to LDM.

1 Reidy MA, Schwartz SM. Endothelial regeneration. III. Time course of intimal changes after small defined injury to rat aortic endothelium. Lab Invest 1981; 44: 301-308.

2 Werner N, Priller J, Laufs U, Endres M, Bohm M, Dirnagl U, Nickenig G. Bone marrowderived progenitor cells modulate vascular reendothelialization and neointimal formation: effect of 3-hydroxy-3-methylglutaryl coenzyme a reductase inhibition. Arterioscler Thromb Vasc Biol 2002; 22: 1567-1572.

3 Imanishi T, Moriwaki C, Hano T, Nishio I. Endothelial progenitor cell senescence is accelerated in both experimental hypertensive rats and patients with essential hypertension. J Hypertens 2005; 23: 1831-1837.

4 Werner N, Kosiol S, Schiegl T, Ahlers P, Walenta K, Link A, Böhm M, Nickenig G. Circulating endothelial progenitor cells and cardiovascular outcomes. $N$ Engl J Med 2005; 353: 999-1007.

5 Imanishi T, Hano T, Nishio I. Angiotensin II accelerates endothelial progenitor cell senescence through induction of oxidative stress. J Hypertens 2005; 23: 97-104.

6 Yao E-H, Fukuda N, Matsumoto T, Kobayashi N, Katakawa M, Yamamoto C, Tsunemi A, Suzuki R, Ueno T, Matsumoto K. Losartan improves the impaired function of endothelial progenitor cells in hypertension via an antioxidant effect. Hypertens Res 2007; 30: 1119-1128.

7 Honda A, Matsuura K, Fukushima N, Tsurumi Y, Kasanuki H, Hagiwara N. Telmisartan induces proliferation of human endothelial progenitor cells via PPAR $\gamma$-dependent PI3K/ Akt pathway. Atherosclerosis 2009; 205: 376-384.

8 Fadini GP, Avogaro A. Cell-based methods for ex vivo evaluation of human endothelial biology. Cardiovasc Res 2010; 87: 12-21.

9 Kim YM, Pae HO, Park JE, Lee YC, Woo JM, Kim NH, Choi YK, Lee BS, Kim SR, Chung HT. Heme oxygenase in the regulation of vascular biology: from molecular mechanisms to therapeutic opportunities. Antioxid Redox Signal 2010; 14: 137-167.

10 Stocker R, Yamamoto Y, McDonagh AF, Glazer AN, Ames BN. Bilirubin is an antioxidant of possible physiological importance. Science 1987; 235: 1043-1046.

11 Aizawa T, Ishizaka N, Taguchi J, Nagai R, Mori I, Tang SS, Ingelfinger JR, Ohno M. Heme oxygenase-1 is upregulated in the kidney of angiotensin II-induced hypertensive rats: possible role in renoprotection. Hypertension 2000; 35: 800-806.

12 Datla SR, Dusting GJ, Mori TA, Taylor CJ, Croft KD, Jiang F. Induction of heme oxygenase-1 in vivo suppresses NADPH oxidase derived oxidative stress. Hypertension 2007; 50: 636-642.

13 Stocker R, Perrella MA. Heme oxygenase-1. A novel drug target for atherosclerotic diseases? Circulation 2006; 114: 2178-2189.

14 Wu BJ, Midwinter RG, Cassano C, Beck K, Wang Y, Changsiri D, Gamble JR, Stocker R. Heme oxygenase-1 increases endothelial progenitor cells. Arterioscler Thromb Vasc Biol 2009; 29: 1537-1542.

15 Naesens M, Steels P, Verberckmoes R, Vanrenterghem Y, Kuypers D. Bartter's and Gitelman's syndromes: from gene to clinic. Nephron Physiol 2004; 96: 65-78.

16 Cal LA. Vascular tone control in humans: the utility of studies in Bartter's/Gitelman's syndromes. Kidney Int 2006; 69: 963-966.

17 Calò LA, Pessina AC, Semplicini A. Angiotensin II signaling in the Bartter' and Gitelman's syndromes, a negative human model of hypertension. High Blood Press Cardiovasc Prev 2005; 12: 17-26

18 Calò LA, Pessina AC. RhoA/Rho-kinase pathway: much more than just a modulation of vascular tone. Evidence from studies in humans. J Hypertens 2007; 25: 259-264.

19 Calò LA, Puato M, Schiavo S, Zanardo M, Tirrito C, Pagnin E, Balbi G, Davis PA, Palatini $P$, Pauletto P. Absence of vascular remodelling in a high angiotensin-II state (Bartter's and Gitelman's syndromes): implications for angiotensin II signalling pathways. Nephrol Dial Transplant 2008; 23: 2804-2809.

20 Calò LA, Montisci R, Scognamiglio R, Davis PA, Pagnin E, Schiavo S, Mormino P, Semplicini A, Palatini P, D'Angelo A, Pessina AC. High angiotensin II state without cardiac remodeling (Bartter's and Gitelman's syndromes). Are angiotensin II type 2 receptors involved? J Endocrinol Invest 2009; 32: 832-836. 
21 Calò L, Ceolotto G, Milani M, Pagnin E, van den Heuvel LP, Sartori M, Davis PA, Costa $\mathrm{R}$, Semplicini A. Abnormalities of Gq-mediated cell signaling in Bartter and Gitelman syndromes. Kidney Int 2001; 60: 882-889.

22 Calò LA, Pagnin E, Davis PA, Sartori M, Ceolotto G, Pessina AC, Semplicini A. Increased expression of regulator of G protein signaling-2 (RGS-2) in Bartter's/ Gitelman's sydrome. A role in the control of vascular tone and implication for hypertension. J Clin Endocrinol Metab 2004; 89: 4153-4157.

23 Calò LA, Pagnin E, Ceolotto G, Davis PA, Schiavo S, Papparella I, Semplicini A, Pessina AC. Silencing regulator of $G$ protein signaling-2 (RGS-2) increases angiotensin II signaling: insights into hypertension from findings in Bartter's/Gitelman's syndromes. $J$ Hypertens 2008; 26: 938-945.

24 Pagnin E, Davis PA, Sartori M, Semplicini A, Pessina AC, Calò LA. Rho kinase and PAI1 in Bartter's/Gitelman's syndromes: relationship to angiotensin II signaling. J Hypertens 2004; 22: 1963-1969.

25 Pagnin E, Semplicini A, Sartori M, Pessina AC, Calò LA. Reduced mRNA and protein content of Rho guanine nucleotide exchange factor (RhoGEF) in Bartter's and Gitelman's syndromes. Relevance for the pathophysiology of hypertension. Am J Hypertens 2005; 18: 1200-1205.

26 Davis PA, Pagnin E, Semplicini A, Avogaro A, Calò LA. Insulin signaling, glucose metabolism and the angiotensin II signaling system. Studies in Bartter's/Gitelman's syndromes. Diabetes Care 2006; 29: 469-471.

27 Calò LA, Davis PA, Palatini P, Semplicini A, Pessina AC. Urinary albumin excretion, endothelial dysfunction and cardiovascular risk: study in Bartter's/Gitelman's syndromes and relevance for hypertension. J Hum Hypertens 2007; 21: 904-906.

28 Calò LA, Schiavo S, Davis PA, Pagnin E, Mormino P, D'Angelo A, Pessina AC. Angiotensin II signaling via type 2 receptors in a human model of vascular hyporeactivity: implications for hypertension. J Hypertens 2010; 28: 111-118.

29 Calò L, Sartore G, Bassi A, Basso C, Bertocco S, Marin R, Zambon S, Cantaro S, D'Angelo A, Davis PA, Manzato E, Crepaldi G. Reduced susceptibility of low density lipoprotein to oxidation in patients with overproduction of nitric oxide (Bartter's and Gitelman's syndrome). J Hypertens 1998; 16: 1001-1008.

30 Calò LA, Pagnin E, Davis PA, Sartori M, Semplicini A. Oxidative stress related factors in Bartter's and Gitelman's syndromes: relevance for angiotensin II signalling. Nephrol Dial Transplant 2003; 18: 1518-1525.

31 Calo L, Davis PA, Milani M, Cantaro S, Antonello A, Favaro S, D'Angelo A. Increased endothelial nitric oxide synthase mRNA level in Bartter's and Gitelman's syndrome. Relationship to vascular reactivity. Clin Nephrol 1999; 51: 12-17.

32 Calo L, D'Angelo A, Cantaro S, Bordin MC, Favaro S, Antonello A, Borsatti A. Increased urinary NO2-/NO3- and cyclic GMP levels in patients with Bartter's syndrome: relationship to vascular reactivity. Am J Kidney Dis 1996; 27: 874-879.

33 Lambiase PD, Edwards RJ, Anthopoulos P, Rahman S, Meng YG, Bucknall CA Redwood SR, Pearson JD, Marber MS. Circulating humoral factors and endothelial progenitor cells in patients with differing coronary collateral support. Circulation 2004; 109: 2993-2999.

34 Fadini GP, Schiavon M, Cantini M, Baesso I, Facco M, Miorin M, Tassinato M, de Kreutzenberg SV, Avogaro A, Agostini C. Circulating progenitor cells are reduced in patients with severe lung disease. Stem Cells 2006; 24: 1806-1813.

35 Asahara T, Murohara T, Sullivan A. Isolation of putative endothelial progenitor cells for angiogenesis. Science 1997; 275: 964-967.

36 Urbich C, Dimmeler S. Endothelial progenitor cells: characterization and role in vascular biology. Circ Res 2004; 95: 343-353.

37 Hill JM, Zalos G, Halcox JP, Schenke WH, Waclawiw MA, Quyyumi AA, Finkel T. Circulating endothelial progenitor cells, vascular function, and cardiovascular risk. $N$ Engl J Med 2003; 348: 593-600.

38 Vasa M, Fichtlscherer S, Aicher A, Adler K, Urbich C, Martin H, Zeiher AM, Dimmeler S. Number and migratory activity of circulating endothelial progenitor cells inversely correlate with risk factors for coronary artery disease. Circ Res 2001; 89: e1-e7.

39 Panza JA, Quyyumi AA, Brush Jr JE, Epstein SE. Abnormal endothelium-dependent vascular relaxation in patients with essential hypertension. N Engl J Med 1990; 323: 22-27.

40 Haendeler J, Hoffmann J, Diehl F, Vasa M, Spyridopoulos I, Zeiher AM, Dimmeler S. Antioxidants inhibit nuclear export of telomerase reverse transcriptase and delay replicative senescence of endothelial cells. Circ Res 2004; 94: 768-775.

41 Plantinga Y, Ghiadoni L, Magagna A, Giannarelli C, Franzoni F, Taddei S, Salvetti A. Supplementation with vitamins $C$ and $E$ improves arterial stiffness and endothelial function in essential hypertensive patients. Am J Hypertens 2007; 20: 392-397.

42 Datla SR, Griendling KK. Reactive oxygen species, NADPH oxidases, and hypertension. Hypertension 2010; 56: 325-330.

43 Rosso A, Balsamo A, Gambino R, Dentelli P, Falcioni R, Cassader M, Pegoraro L, Pagano G, Brizzi MF. p53 Mediates the accelerated onset of senescence of endothelial progenitor cells in diabetes. J Biol Chem 2006; 281: 4339-4347.

44 Zhou Z, Peng J, Wang C-J, Li D, Li T-T, Hu C-P, Chen XP, Li YJ. Accelerated senescence of endothelial progenitor cells in hypertension is related to the reduction of calcitonin gene-related peptide. J Hypertens 2010; 28: 931-939.

45 Peng J, Lu R, Ye F, Deng H-W, Li Y-J. The heme oxygenase pathway is involved in calcitonin gene-related peptide-mediated delayed cardioprotection induced by monophosphoryl lipid A in rats. Regul Pept 2002; 103: 1-7.

46 Timmermans F, Plum J, Yöder MC, Ingram DA, Vandekerckhove B, Case J. Endothelial progenitor cells: identity defined? J Cell Mol Med 2009; 13: 87-102.

47 Hirschi KK, Ingram DA, Yoder MC. Assessing identity, phenotype, and fate of endothelial progenitor cells. Arterioscler Thromb Vasc Biol 2008; 28: 1584-1595.

48 Fadini GP, Baesso I, Albiero M, Sartore S, Agostini C, Avogaro A. Technical notes on endothelial progenitor cells: ways to escape from the knowledge plateau. Atherosclerosis 2008; 197: 496-503. 